\title{
Realigning Vocational Skills for Employment and Self Employment of Hearing- Impaired Youths: The Case of Masvingo-Peri Urban
}

\author{
Chenjerai Muwaniki, Patricia Muvirimi \\ Great Zimbabwe University, Zimbabwe \\ chenjerai.muwaniki@gmail.com, trishmuv@gmail.com
}

\begin{abstract}
The study sought to investigate the prospects of equipping hearing impaired youths in peri-urban Masvingo District with skills for employment and self-employment in view of the economic crisis in Zimbabwe. The study used the Human Capital Theory as the theoretical framework. A case study research design was used. Data was collected through semi-structured interviews of eight purposefully selected hearing impaired vocational graduates as well as four key informant interviews with lecturers at the special school. Observations were also done to augment data from the interviews. Thematic analysis was used in analysing the data. The study revealed that the hearing-impaired graduates acquired technical and vocational and skills at the special school. However, despite the high skill levels, they were not being utilised for their livelihoods. Instead of utilising their technical and vocational skills, most of the graduates were engaged in self initiated micro-entrepreneurial activities such as street vending. The major challenges to employment and self-employment included lack of capital, communication barriers and lack of representation and clear policy. The study recommends the realignment of vocational skills with the reality in which hearing impaired graduates experience daily to focus more on entrepreneurship and community development in view of a weak economy which makes employment and self-employment difficult to achieve.
\end{abstract}

Keywords: Vocational skills, hearing impaired youth, employment, and self-employment, economic crisis

\section{Introduction}

Zimbabwe has made significant progress in the provision of both general and vocational education to its youths and adults with disabilities since attaining independence in 1980. Soon after Zimbabwe's independence, the new government began to coordinate and manage the education for the hearing impaired in line with the move towards providing equal opportunities for all (E Mpofu, Kasayira, Mhaka, Chireshe, \& Maunganidze, 2007; Peresuh \& Barcham, 1998).However, in recent years these youths have been operating at the periphery of the economy. This paper is premised on the notion that vocational skills offered to youths with disabilities in Masvingo peri-urban area of Zimbabwe is failing to improve the livelihoods of hearing impaired graduates and is in need of re-alignment to the current economic realities in order to enhance the graduates' employment and employability. The study was limited to hearing-impaired vocational graduates from a special school in Masvingo peri-urban. This paper starts by discussing the arguments for vocational education for youths with disabilities, the economic crisis in Zimbabwe and presents alternative directions for re-aligning vocational education for the hearing impaired to improve their employability. Equipping people with disabilities with vocational skills is widely believed to improve their chances of accessing employment opportunities as well as improving their participation in self-employment. Research has shown that people with disabilities are usually disadvantaged in regards with employment opportunities due to their lower access to education including vocational education(Barnes \& Mercer, 2005; Eide \& Ingstad, 2017; World Health Organization, 2015). Recent studies in the United Kingdom, South Korea and Ghana have revealed that people with disabilities have less access to vocational education programs as such; they do not enjoy the benefits of vocational training such as participation in the labor market through employment(Chun, Connor, Kosciulek, Landon, \& Park, 2016; Gyamfi, Mprah, Edusei, Dogbe, \& Owusu, 2016). In Uganda it has been revealed that inequality in employment is one of the stumbling blocks to social and economic development(Nyombi \& Kibandama, 2016).

In the Zimbabwean context research has confirmed similar challenges in accessing work for persons with disabilities. Choruma (2007) aptly describes people with disabilities in Zimbabwe as a forgotten tribe in reference to their marginalization. In other studies, employers have been found to be skeptical in employing the disabled (Hlatywayo \& Ncube, 2014; Kaserera, 2012). There are only a few studies on disability and employment in Zimbabwe as is the case for studies on skills development for the poor in general (Bennell et al., 1999). A study by (Musengi, Ndofirepi, \& Shumba, 2012) revealed that current data on participation of the 
hearing impaired in general education is unknown. Residential schools offering vocational skills training for the hearing impaired in Masvingo province include the Henry Murray School for the deaf at Morgenster Mission and the Jairos Jiri training centre. These special schools in Zimbabwe focus on vocational skills in fields such as metal work, welding, fashion and fabrics and agriculture, this is also the trend in the United States of America (Chitiyo \& Wheeler, 2004; Musengi et al., 2012).There is still need for more research on employability of people with disability in Zimbabwe hence this study which focuses on vocationally trained hearing impaired youths in a special school. The study sought to address the following two research questions:

- What are the employability skills needed by hearing impaired VET learners in view of the economic crisis in Zimbabwe?

- How should the VET skills training for the hearing impaired be realigned to meet the need for employment and self-employment?

The terms vocational education and employability are defined in the following section:

Vocational Education and Training: There are so many definitions of the concept Vocational Education and Training (Billet, 2011). Vocational training involves teaching people to acquire a particular skill meant to prepare them for a particular occupation. According to UNESCO, VET is concerned with the acquisition of knowledge and skills for the world of work. In the Zimbabwean context, Technical and Vocational Education is used to describe technical education and vocational education as a whole inclusive of training done on the job as well as in training institutions (Ministry of Higher and Tertiary Education, 2005).

Employability: The issue of employability has occupied centre stage in VET in recent years. The concept employability means different things to different people. In this paper the definition Hillage and Pollard (1998, p. 1) is adopted which spells out that employability is about having the capability to gain initial employment, maintain employment and obtain new employment if required. This definition is crucial in that it identifies key elements which determine employability including the possession of assets in terms of the knowledge, skills and attitudes they posses, the way they use and deploy those assets, the way they present them to employers, and crucially, the context including the circumstances in the labor market (Hillage \& Pollard, 1998).

\section{Literature Review}

The purpose of this literature review is to show the importance of vocational education for people with disabilities. In doing so, the Human Capital Theory (HCT), was used as the theoretical framework for the study. The Human Capital Theory emphasizes the role of education in increasing the productivity and efficiency of workers (Nafukho, Hairston, \& Brooks, 2004; Olaniyan \& Okemakinde, 2008). Education therefore is considered to be an investment in the same way money is considered capital. As applied to the current study, an investment on hearing-impaired youth through vocational education will likely make them more productive for their organizations and society as a whole. Vocational education and training (VET) has been commended for contributing to development on the global level and has regained attention of policy makers and researchers(McGrath et al., 2006; Vaz, 2012).According toUNESCO (2016) globally, vocational education is being used to address a range of concerns including rising youth unemployment, poverty and gender inequality. It is against that backdrop that most countries have made significant investments in VET to equip youths and adults with skills for employment and self-employment. It has long been observed that without skills to sell on the labor market or to use in self-employment, individuals are much more likely to be in poverty(King \& McGrath, 2002; McGrath, Akoojee, Gewer, \& Roberts, 2006). This is worse for those who are differently-abled. Equipping the differently-abled with vocational skills is a critical component of the poverty reduction as anticipated in the Sustainable Development Goals (SDGs) 2016- 2030. In terms of VET provision specifically the UNESCO-TVET Strategy for 2016 to 2021 is at the centre of informing government policies (UNESCO, 2016). Of particular relevance are goal 4(quality education) and goal 8(decent work and economic growth) of the SDGs (UNESCO, 2016). The TVET Strategy focuses on the need to transform the TVET sector so that it reflects the current social, economic, technological and environmental landscape on the global scale. The changes in the nature of the labor market and trends in youth employment make the reforms even more urgent. 
TVET has the power and potential to transform lives through enhancing people's employability and access to jobs, enabling labor market progression and promoting 'decent work' by, for example, increasing people's incomes and also reduce exclusion from the job market irrespective of race, gender, social position and disability(UNESCO, 2016, p. 5). Despite having clear roles for TVET in society, most of the time it fails to achieve its intended goals hence UNESCO realized the need to realign TVET to meet expectations of an ever changing global community. There has been a focus on enhancing the employability of disabled VET students for them to be able to participate in the labor market (Riddell, Baron, \& Wilson, 2001). The unemployment of people with disabilities is higher than for the non-disabled (Harvey, 1998, 2001; Wagner, 1991). The transition from school to work has attracted significant attention in the field of special education and vocational education is one of the bridges linking the two. However, the efficacy of vocational training in increasing employment and self employment of graduates has not received adequate attention (Harvey, 2001).

The UNESCO TVET strategy identified the following six key areas of focus for TVET for the next five years; Access to TVET, Quality of TVET, TVET Governance, Private sector involvement, TVET institutions and Funding. The first two focal areas of access and quality are quite relevant especially in relation to VET provision for people with disabilities. Often times they have limited access to VET opportunities and where they eventually get access, the quality of provision often times is poor. Quality was again discussed, particularly in terms of outputs that are valued by employers, which has implications for the measurement of TVET success (UNESCO, 2016).The UNESCO TVET strategy outlines four key principles that should guide TVET provision, however only two are presented because of their close association with the current study:

- TVET provides opportunities to acquire better access to decent work. It provides 'skills for jobs' however cannot create these jobs. In this context, TVET should adopt a holistic approach, preparing people for life outside work in the wider society;

- TVET should also focus on providing other skills, in particular entrepreneurial skills, as these can help people create their own jobs when jobs are not available in sufficient numbers (UNESCO, 2016, p. 7).

It is uncontested that people equipped with vocational skills are more likely to have better livelihoods if they make use of their skills in employment and self-employment. It should be noted that about $80 \%$ of youths with disabilities live in developing countries (World Bank, 2005; UNDESA, 2012). These youths face challenges that are not unique from those of others including lack of access to education, health-care, social services and employment. However, the little literature available on employment of youth with disabilities suggests that they are affected by these challenges in more complex ways as compared to those without any disabilities(Kett, 2012). Youths with disabilities in developing countries have limited access to mainstream vocational education institutions and have also limited participation in the formal labor market(Bennell et al., 1999). Recent studies have shown that youths with disabilities experience employment and employability challenges (Chun et al., 2016; Guilbert, Bernaud, Gouvernet, \& Rossier, 2016).Zimbabwe is considered to be one of the most disability friendly countries on the African continent due to its supportive legislation as well as economic and education policies for the differently-abled(Musengi et al., 2012). Zimbabwean legislation on disability includes the Disabled Persons Act of 1996, Section 22 of the Constitution of Zimbabwe Amendment No 20. These legislations recognize the role of the differently-abled in Zimbabwe including their participation in education and employment. Elias Mpofu and Harley (2002) note that the country has made significant investments in its vocational training system ahead of many others on the continent. The government of Zimbabwe is a significant player in the provision of VET however; there is also the participation of non-governmental organizations and the private sector.

The Economic crisis and vocational education in Zimbabwe: Zimbabwe has experienced successive economic crisis from the early 1990s onwards. The crisis was triggered by economic liberalization policies and Structural Adjustment Programs prescribed by the Bretton Woods institutions. The policies affected the provision of social services including education and health (Nyazema, 2010; Vurayai \& Muwaniki, 2016). More recently the economic crisis was worsened by sanctions imposed on the country after implementing the Fast Track Land Reform Program as well as poor economic stewardship(Groves, 2009; Mabhena, 2010). The economic crisis in Zimbabwe had obvious challenges on the operations of vocational training institutions and education provision in the country as revealed by the Presidential Commission on Education of 1999, 
popularly referred to as the Nziramasanga Commission Report. Findings of the report revealed that most educational institutions were affected by the economic challenges in Zimbabwe compromising provision of knowledge and skills to learners. Other related studies have revealed that the challenges include decline in student enrollment, collapse of infrastructure and brain drain among others (Kanyenze, Kondo, Chitambira, \& Martens, 2011; Nyazema, 2010; Nziramasanga, 1999). More recent studies on the impact of the economic crisis on education have also revealed that aspects such as teacher professionalism have also been negatively affected by the crisis (Vurayai \& Muwaniki, 2016). Skills training centres were more affected by the crisis because more often they need consumables for practical subjects that are difficult to obtain when the economy is not performing well. In view of the economic crisis in Zimbabwe the researchers assumed that vocational education skills training programs for the hearing impaired youths in Masvingo peri-urban could be facing challenges in achieving the goals of employment and self-employment hence the study.

\section{Methodology}

A case study design was used in this study (Rule \& John, 2011; Yin, 2013). This study was done with graduates from a special school offering vocational education and training to differently-abled youths in Masvingo peri-urban. The special school selected has special focus on hearing impaired youths. Qualitative research is conducted through intense prolonged contact with research participants (Miles \& Huberman, 1994 ).Qualitative research is the best approach for this study to explore the social inclusion of individuals with disabilities(Hall, 2009, p. 163).Purposive sampling was used in the selection of study participants' hearing impaired vocational skills graduates who attended the special school in Masvingo peri-urban. The participants were eight graduates and four lecturers from the institution. The participants were from the following trades; welding, building, clothing and textile as well as wood work. Of the four lecturers, three were non-hearing impaired and only one was hearing impaired. Of these participants five were male and seven female.

Data collection and Analysis: Data was collected data using semi- structured interviews for the eight graduates. On the other hand, data from the vocational lecturers was collected using key informant interviews. A qualified research assistant helped in collecting data from the hearing impaired graduates using sign language. The assistant was asking the questions as well as recording the responses verbatim. Data was analyzed using qualitative data analysis which used the following steps: data reduction, coding and categorization into themes(Creswell, 2013; Miles \& Huberman, 1994 ). Thematic analysis is regarded as an accessible and theoretically flexible approach to analyzing qualitative data(Braun \& Clarke, 2006).The major themes that emerged from the data and were supported by rich quotes where it was deemed necessary.

Methodological Rigor: Rigor is an important aspect to consider in research studies. It refers to the means by which researchers demonstrate integrity and competence(Tobin \& Begley, 2004). In this study aspects of trustworthiness and ethics were considered to uphold rigor. In this study applicability, consistency and neutrality were considered as aspects to enhance trustworthiness (Guba \& Lincoln, 1994). As expected in research, care was taken to avoid violation of ethics. Ethical issues are important is research studies which involve the participation of humans as well as animals(Denscombe, 2014). Observing ethics become more important when dealing with vulnerable participants such as children or people with disabilities(Aldridge, 2014). In this study informed consent was addressed through informing all the participants of the purpose of the study as well as their freedom to withdraw at anytime

\section{Results and Discussion}

This section discusses the major findings of the study based on the two main research questions of the study.

Employability skills needed by hearing impaired graduates in the context of economic crisis: Evidence from the study from both the key informant interviews with vocational lecturers and the semi-structured interviews with graduates showed congruency on the major issues under study. The hearing impaired vocational graduates felt that the vocational skills they received from the special school gave them motor skills which they previously did not have. However their expectation after the training was to get employment in the trades they trained in as well as assist others who wanted to be self-employed. The 
vocational graduates were united in their frustration with the training they received in that it emphasized acquisition of technical skills in trades such as welding, building, wood work and clothing and textile without including employability skills.

Realigning vocational skills training programs for hearing impaired: Related to the above finding are issues to do with including work related learning in the curriculum, broadening vocational profile of learners, use of industry specific technology and entrepreneurship training.

Work related learning: The current vocational skills training program offered at the special school does not have compulsory work related learning which exposes students to the real world of work. As a result graduates are not well prepared for entry into the labor market upon completion of the training. These sentiments were shared by both the graduates and the lecturers interviewed. The following are some of the excerpts from the interviews:

Lecturer 1: Our program is entirely institution based as a result our graduates complete without industrial exposure. This affects their participation in the labor market because employers prefer those who did attachment.

Lecturer 2: Employers have negative perceptions on our program. This is compounded by the fact that our students are unique in that they are hearing impaired. I think we need to expand enrolment to make it inclusive of non-disabled youths to show employers that we are equally competitive.

Student 1: We need industry exposure in our program so that we work together with the hearing co-workers as well. Sign language must also be recognized in work places as a normal language just as English and Shona.

Student 2: Our training program needs to emphasize both technical skills and other skills that enhance our chances of labor market participation.

The need for work experience to enhance graduate employability in VET and Higher Education Institutions (HEI) has also been confirmed in several studies in recent years (Dacre Pool \& Sewell, 2007; Working Experience Group, 2002). The Working Experience Group (2002, p. 4)note that employers value people who have undertaken work experience in the real world of work to develop their competency. Vocational training colleges need to understand the learning and teaching experience in more complex ways than is usually associated with projects that aim to enhance employability such as industry partnerships or work experience programs (McGrath, Needham, Papier, Wedekind, \& van der Merwe, 2010b; Wedekind \& Mutereko, 2016). Participation of students in work related learning is one of the key factors for the success of vocational education programs (Mabhanda, 2016). This applies to all colleges and even special schools for the differently-abled people since the labor market is not divided.

Use of appropriate technology relevant to industry: The economic crisis in Zimbabwe has had obvious challenges on the ability of vocational institutions to invest in technology for teaching and learning. Lecturers also lamented the lack of current technology in their programs such as the one used in industries. The investment in technology has been hampered by the poor performance of the economy over the past twenty years. The following quotations are quite revealing on the challenges faced as a result of poor technology.

Lecturer1: In my program, we have not adopted computer technology for teaching and learning. Computers are not even prioritized at all and I don't think they are necessary in building.

Lecturer 2: In metal work, there are some activities which we do not do because we do not have the necessary equipment such as lathe machines used by technical colleges. As a result our students do not cover the whole curriculum.

In order to enhance approximation between industry requirements and the learning environment at the local institution, there is need to create working linkages between the institutions whereby industry also invests in infrastructure development for the training centres. This is in line with Wedekind and Mutereko (2016, p. 379 ) findings that given the rapid pace of social and technological change, educational institutions need to be flexible and adaptable to the needs of employers.

Broader vocational profiles: Graduates from the special school revealed that currently once they choose a particular program they are confined to it and do not learn any other subjects. In their view, this affects their employability. Some graduates interviewed made the following responses: 
Graduate 1: Our school emphasizes specialization in a field that you have been placed in. Some of these placements are just made at Administration office and sometimes you are given a field you are not interested in.

Graduate 2: The Lecturers in the schools need to have students in their classes at any one time. As a result of low student enrollments they just divide the number of students with the programs available without even looking at the labor market.

Graduate 3: In cases where educational guidance is offered to us when we start courses, it has been biased deliberately by the lecturers because they do not want to lose students to other programs and we end up studying for qualifications that are not marketable.

Graduates under study had limited vocational profiles, in that one had to make a single choice of program of specialization. For increased employability, there is need to expand programs for example one can study building and wood work simultaneously. This broadens the skill base of the graduate in that apart from being able to build houses one now has roofing skills as well. This enhances the chances of these hearing impaired graduates to compete on the labor market once they have broader skills. The importance of broadening vocational profiles of learners been emphasized in earlier studies(Working Experience Group, 2002)

Curriculum responsiveness to local realities: Colleges need to take note of the local realities in which they operate and as such their curriculum should be responsive to changes in the labor market to improve graduate employability. Findings from the study have revealed that employability of graduates from the special school under study has been also worsened by poor curriculum responsiveness to prevailing circumstances in the economy. This was confirmed by the lecturers. The following quotations from the interviews with some lecturers reveal poor curriculum responsiveness:

Lecturer 1: The programs that we offer have not been reviewed or changed since the opening of the school. I came here more than ten years ago and there have not been any changes.

Lecturer 2: Our curriculum is mostly closed, with little input from outside of the institution as such we lag behind developments in the labor market.

The above quotations from interviews with the lecturers are quite revealing on the poor curriculum responsiveness at the institution and this has a bearing on graduate employability. There is evidence of poor quality assurance by the institution and this affects the quality of graduate produced by the college. Previous studies on curriculum responsiveness and employability in VET have revealed that vocational curriculum should respond to the needs of employers, the economy students and the requirements of a particular discipline (Moll, 2004; Wedekind \& Mutereko, 2016).

\section{Conclusion and Recommendations}

The study revealed that there is a misalignment of vocational skills training for hearing impaired youths at the special school studied as a result of the economic crisis in the country. There is a need for the realignment of vocational training for hearing impaired youths with the realistic employment and self employment opportunities available. There is need for vocational policy that encourages inclusive education as well as offering disability specific training programs that are in-line with labor market requirements. The government of Zimbabwe should also consider employment quarters which encourage the employment of people with disabilities in areas where they have skills. Companies which comply with this requirement need to be encouraged by the government through tax exemptions in certain cases. Another aspect is in relation to work environments which need to be accessible for all people, with or without disabilities. There is need to encourage all stakeholders in vocational training of hearing impaired youths to promote employment and self-employment opportunities for these graduates. Vocational graduates need to be supported financially and materially to start their own enterprises. It also emerged that vocational training should be contextualized and responsive to the nature of learners' disabilities. Vocational training needs to expand its focus from labor market to non-labor market imperatives.

\section{References}


Aldridge, J. (2014). Working with vulnerable groups in social research: dilemmas by default and design. Qualitative Research, 14(1), 112-130.

Barnes, C. \& Mercer, G. (2005). Disability, work, and welfare: challenging the social exclusion of disabled people. Work, employment and society, 19(3), 527-545.

Bennell, P., Bendera, S., Kanyenze, G., Kimambo, E., Kiwia, S., Mbiriyakura, T.\& Parsalaw, W. (1999). Vocational Education and Training in Tanzania and Zimbabwe in the Context of Economic Reform. Education Research Paper: ERIC.

Billet, S. (2011). Vocational Education Purposes, Traditions and Prospects. New York: Springer.

Braun, V., \& Clarke, V. (2006). Using thematic analysis in psychology. Qualitative Research in Psychology, 3(2), 77-101.

Chitiyo, M.\& Wheeler, J. (2004). The Development of Special Education Services in Zimbabwe. International Journal of Special Education, 19(2), 46-52.

Choruma, T. (2007). The forgotten tribe: People with disabilities in Zimbabwe: CIIR.

Chun, J., Connor, A., Kosciulek, J. F., Landon, T.\& Park, J. (2016). Career Development for Youth with Disabilities in South Korea: The Intersection of Culture, Theory, and Policy. Global Education Review, 3(3), 57-74.

Creswell, J. W. (2013). Research design: Qualitative, quantitative, and mixed methods approaches: Sage publications.

Dacre Pool, L.\& Sewell, P. (2007). The key to employability: developing a practical model of graduate employability. Education+ Training, 49(4), 277-289.

Denscombe, M. (2014). The good research guide: for small-scale social research projects: McGraw-Hill Education (UK).

Eide, A.\& Ingstad, B. (2017). Disability and poverty: A global challenge: Policy Press.

Groves, R. (2009). Fast-track Land Reform And The Decline Of Zimbabwe's Political And Economic Stability.

Guba, E. G.\& Lincoln, Y. S. (1994). Competing paradigms in qualitative research. Handbook of qualitative research, 2(163-194), 105.

Guilbert, L., Bernaud, J. L., Gouvernet, B. \& Rossier, J. (2016). Employability: review and research prospects. International Journal for Educational and Vocational Guidance, 16(1), 69-89.

Gyamfi, N., Mprah, W. K., Edusei, A. K. E., Dogbe, J. A.\& Owusu, I. (2016). Relevance of vocational training programme for persons with disabilities in the Ashanti Region of Ghana. Journal of Disability Studies, $1(2), 69-76$.

Hall, S. A. (2009). The social inclusion of people with disabilities: a qualitative meta-analysis. Journal of ethnographic \& qualitative research, 3(3).

Harvey, M. W. (1998). The relationship of postsecondary transitional outcomes and participation in secondary vocational technical education among students with disabilities. Pennsylvania State University.

Harvey, M. W. (2001). The efficacy of vocational education for students with disabilities concerning postschool employment outcomes: A review of the literature.

Hillage, J.\& Pollard, E. (1998). Employability: developing a frame work for policy analysis. London: Department of Education and Employment.

Hlatywayo, L.\& Ncube, A. C. (2014). Employing Deaf Persons: A Zimbabwean Employers Perspective. International Journal of Innovative Research and Development, 3(10).

Kanyenze, G., Kondo, T., Chitambira, P.\& Martens, J. (2011). Beyond the enclave: Towards a pro- poor and inclusive development strategy for Zimbabwe. Harare: Weaver Press.

Kaserera, J. (2012). Assessing the impact of mainstream vocational training in developing capabilities of people with and without disabilities. A case of Danhiko Training Institution in Harare, Zimbabwe. Institute of Social Studies, The Hague, Netherlands.

Kett, M. (2012). Skills development for youth living with disabilities in four developing countries. Background paper for EFA Global Monitoring Report.

King, K.\& McGrath, S. (2002). Globalisation, enterprise and knowledge: Education, training and development in Africa.

Mabhanda, W. (2016). Industrial Attachment challenges: Lessons drawn from Gweru Polytechnic College in Zimbabwe. International Journal of Business and Management Invention, 5(9), 37-42. 
Mabhena, C. (2010). Visible hectres, vanishing livelihoods: A case of the Fast Track Land Reform Programme in southern Matebeleland- Zimbabwe. (PhD), Fort- Hare, South Africa.

McGrath, S., Akoojee, S., Gewer, A., Mabizela, M., Mbele, M.\& Roberts, C. (2006). An examination of the vocational education and training reform debate in Southern Africa. Compare, 36(1), 85-103.

McGrath, S., Akoojee, S., Gewer, A.\& Roberts, J. (2006). An examination of the vocational education and training reform debate in Southern Africa. Compare, 36(1), 85-103.

McGrath, S., Needham, S., Papier, J., Wedekind, V.\& van der Merwe, T. (2010b). Employability in the College Sector: A Comparative Study of England and South Africa. Final Report of the Learning to Support Employability Project. School of Education, University of Nottingham.

Miles, M. B.\& Huberman, A. M. (1994 ). Qualitative data analysis: A sourcebook of new methods Thousand Oaks, CA: Sage.

Ministry of Higher and Tertiary Education. (2005). Technical and Vocational Education and Training policy review framework (pp. 1-58).

Moll, I. (2004). Curriculum responsiveness: The anatomy of a concept. In H. Griesel (Ed.), Curriculum Responsiveness: Case Studies in Higher Education. Pretoria: SAUVCA.

Mpofu, E.\& Harley, D. A. (2002). Disability and rehabilitation in Zimbabwe: lessons and implications for rehabilitation practice in the US. Journal of rehabilitation, 68(4), 26.

Mpofu, E., Kasayira, J., Mhaka, M., Chireshe, R.\& Maunganidze, L. (2007). Inclusive education in Zimbabwe. Responding to the challenges of inclusive education in Southern Africa, 66-79.

Musengi, M., Ndofirepi, A.\& Shumba, A. (2012). Rethinking education of deaf children in Zimbabwe: Challenges and opportunities for teacher education. Journal of deaf studies and deaf education, 18(1), 62-74.

Nafukho, F. M., Hairston, N.\& Brooks, K. (2004). Human capital theory: Implications for human resource development. Human Resource Development International, 7(4), 545-551.

Nyazema, N. Z. (2010). The zimbabwe crisis and the provision of social services health and education. Journal of Developing Societies, 26(2), 233-261.

Nyombi, C.\& Kibandama, A. (2016). Access to Employment for Persons with Disabilities in Uganda. Retrieved 17 October 2017, from Cornell University ILR School http://digitalcommons.ilr.cornell.edu/gladnetcollect/569

Nziramasanga, C. T. (1999). Report of the Presidential Commission of Inquiry into Education and Training. Harare: Government Printers.

Olaniyan, D.\& Okemakinde, T. (2008). Human capital theory: Implications for educational development. Pakistan Journal of Social Sciences, 5(5), 479-483.

Peresuh, M.\& Barcham, L. (1998). Special education provision in Zimbabwe. British Journal of Special Education, 25(2), 75-80.

Riddell, S., Baron, S.\& Wilson, A. (2001). The learning society and people with learning difficulties: Policy Press.

Rule, P.\& John, V. (2011). Your guide to Case study research. Johannesburg: Van Schaik Publishers.

Tobin, G. A. \& Begley, C. M. (2004). Methodological rigour within a qualitative framework. Journal of advanced nursing, 48(4), 388-396.

UNESCO. (2016). UNESCO- TVET Strategy 2016 - 2021. Bonn, Germany: UNESCO.

Vaz, G. (2012). Integrating Vocational Education with Academic Education in Commonwealth Open School: Commonwealth of Learning (COL).

Vurayai, S.\& Muwaniki, C. (2016). Zimbabwe's economic crises and the state of proffessionalism among rural secondary school teachers. Dzimbabwe Journal of Multidisciplinary Research, 1(1), 64-74.

Wagner, M. (1991). Youth with disabilities: How are they doing? The first comprehensive report from the National Longitudinal Transition Study of Special Education Students.

Wedekind, V.\& Mutereko, S. (2016). Employability and curriculum responsiveness in post-school education and training.

Working Experience Group. (2002). Work Related Learning Report. Nottingham.

World Health Organization. (2015). WHO global disability action plan 2014-2021: Better health for all people with disability: World Health Organization.

Yin, R. K. (2013). Case study research: Design and methods: Sage publications. 